\title{
Helminth community structure of the oven frog Leptodactylus latinasus (Anura, Leptodactylidae) from Corrientes, Argentina
}

\author{
Monika I. Hamann ${ }^{*}$, Cynthya E. González and Arturo I. Kehr \\ Consejo National de Investigaciones Científicas y Técnicas, Centro de Ecología Aplicada del Litoral, C.C. 291, 3400-Corrientes, \\ Argentina
}

\begin{abstract}
A total of 36 adult individuals of Leptodactylus latinasus were collected near the city of Corrientes, Province of Corrientes in Argentina. The main goals of this study were: (1) to determine the helminth parasite fauna of $L$. latinasus; (2) to determine the richness and diversity of parasites at the component and infracommunity levels; (3) to analyze the relationships between helminth, frog body size and sex; and (4) to identify and examine species affinity of helminth communities. The helminth component community of this frog's population consisted of 17 species. The predominant groups of parasites were the trematodes (adults: Glypthelmins repandum, Catadiscus inopinatus and Haematoloechus longiplexus; larvae: Travtrema aff. stenocotyle, Bursotrema aff. tetracotyloides, Styphlodora sp., unknown opisthogonimid species, Petasiger sp. and unknown strigeid species), followed by the nematodes (Cosmocerca podicipinus, C. parva, C. rara, C. cruzi, Schrankiana schranki and Aplectana hylambatis); other groups of parasites were represented by only one species (unknown larval cestode species and Centrorhynchus sp.). All parasite helminth species showed an aggregated pattern of distribution. The most infected organs were kidneys, small intestine, large intestine and pharyngeal zone. The host body size was important in determining the parasites abundance of G. repandum. At the level of component community G. repandum was the species with highest prevalence of infection and Bursotrema aff. tetracotyloides was the dominant species. Helminth species showed four significant pairs of covariation and two significant pairs of association in the infracommunities of Leptodactylus latinasus.
\end{abstract}

\section{Key words}

Parasite ecology, helminth parasites, Anura, Leptodactylus latinasus, Argentina

\section{Introduction}

Studies on the helminth communities of amphibians in the northern hemisphere have increased in recent years. These studies demonstrated that the parasite community structure depended on many different factors, including both host and parasite life histories (i.e., coevolution) (Janovy et al. 1992, Brooks et al. 2006), the host's characteristic habitat, and host feeding preferences (McAlpine and Burt 1998, Muzzall 1991, Muzzall et al. 2001, Bolek and Coggins 2003, Zelmer et al. 2004). In addition, host species, body size and sex (Tucker and Joy 1996; McAlpine 1997; Joy and Pennington 1998; Bolek and Coggins 2001; Goldberg and Bursey 2002; Goldberg et al. 2002a, b) are important factors in the intricate inter-relationships between parasites and their host in addition to the colonization probabilities of parasites. In Argentina, despite the great diversity of amphibian's fauna (Frost 2004), this area of research is only beginning (Kehr et al. 2000, Kehr and
Hamann 2003, Hamann et al. 2006). Nevertheless, the helminth parasites of amphibians have been analyzed primarily at the infrapopulation level. These studies have reported that the seasonal maturation of parasites in the host is likely dictated by environmental conditions, such as rainfall and dry periods, since temperature is not a limiting factor in determining seasonal maturation on parasites in the Corrientes Province (Hamann 2004, 2006). On the other hand, biotic (e.g., host body size) characteristic are one of the factors that is likely associated with parasitic infections (Hamann and Kehr 1998, 1999a, b).

The present study analyzes the infracommunity of helminth parasites in the frog Leptodactylus latinasus Jiménez de la Espada, 1875. This frog belongs to the fuscus group within the genus Leptodactylus (Fitzinger, 1826). Adult L. latinasus can survive in both dry and moist substrata, i.e. near to the shore of temporary, semipermanent and permanent ponds, and also in the flooded grass. It may be considered as a generalist feeder with a foraging strategy intermediate between sit-and- 
wait and an actively foraging predator (Duré and Kehr 2004). L. latinasus is distributed in Argentina in the provinces of: Buenos Aires, Córdoba, Santa Fé, Chaco, Formosa, Entre Ríos, Corrientes and Misiones, and also occurs in Uruguay and Brazil (Frost 2004).

The main goals of this study were: (1) to report the helminth parasite fauna of L. latinasus; (2) to determine the richness and diversity of parasites at the component and infracommunity levels; (3) to analyze the relationships between helminth, frog body size and sex; and (4) to identify and examine species affinity of helminth communities.

\section{Materials and methods}

\section{Study area}

Study area is located in the northwest of the Province of Corrientes in Argentina $\left(27^{\circ} 27^{\prime} \mathrm{S}, 58^{\circ} 47^{\prime} \mathrm{W}\right)$. The predominant vegetation of the study area is forest, with herbaceous strata composed of grasslands, numerous cacti and terrestrial bromeliads. Also, temporary, semipermanent and permanent ponds characterize the habitat.

\section{Analytical procedure}

Samples of L. latinasus were collected in September 2002 ( $\mathrm{n}=5$ specimens), and from January to November 2003 (January $=3$ specimens, February $=2$, March $=4$, May $=4$, September $=14$, October $=2$ and November $=2$ ). Frogs were handcaptured, mainly at night, using the sampling technique defined as "visual encounters survey" (Crump and Scott 1994). Frogs were transported live to the laboratory, killed in a chloroform solution; and their snout-vent length (SVL) and body weight were recorded. At necropsy, hosts were sexed and the oesophagus, stomach, gut, lungs, liver, urinary bladder, kidneys, body cavity, musculature, integument and brain examined for parasites. Helminths were observed in vivo, counted, killed in hot distilled water and preserved in $70 \%$ ethyl alcohol. Digeneans, cestodes, and acanthocephalans were stained with hydrochloric carmine, cleared in creosote and mounted in Canada balsam. Nematodes were cleared in glycerine or lactophenol, and examined as temporary mounts. The systematic determination of the helminths was carried out following the approaches given by Yamaguti (1961, 1963, 1971, 1975), Anderson et al. (1974), Gibson et al. (2002) and Jones et al. (2005). Specimens of parasite species were deposited in the Helminthological Collection of Centro de Ecología Aplicada del Litoral (CECOAL), Consejo Nacional de Investigaciones Científicas y Técnicas (CONICET), Corrientes, Argentina [accession numbers CECOAL: 03092406, Glypthelmins repandum (Rudolphi, 1819); 03092404, Catadiscus inopinatus Freitas, 1841; 03042402, Haematoloechus longiplexus Stafford, 1902; 05022430, Styphlodora sp.; 03092401, Bursotrema aff. tetracotyloides Szidat, 1960; 03092404, Travtrema aff. stenocotyle Cohn, 1902; 03022001, unknown opisthogonimid species; 03091002, Petasiger sp;
02113237, unknown cestode species; 03052907, Cosmocerca podicipinus Baker et Vaucher, 1984; 03051609, Cosmocerca parva Travassos, 1925; 03092404, Cosmocerca rara Freitas et Vicente, 1966; 03092405, Cosmocerca cruzi Rodriguez et Fabio, 1970; 0301333, Aplectana hylambatis (Baylis, 1927); 03023524, Schrankiana schranki (Travassos, 1925); 03052908, Centrorhynchus sp.].

\section{Statistical analysis}

The infection prevalence, intensity and abundance were calculated for helminths according to Bush et al. (1997). The measures of community richness and diversity employed included: The total number of helminth species (= richness), Shannon's index $\left(\mathrm{H}^{\prime}\right)$ (Shannon and Weaver 1949), and evenness $\left(\mathrm{J}^{\prime}\right)$ as $\mathrm{H}^{\prime} / \mathrm{H}^{\prime}$ maximum (Pielou 1966, Zar 1996). Mean helminth species richness is the sum of helminth species per individual frog, including uninfected individuals, divided by the total sample size. The diversity index was used with decimal logarithms $\left(\log _{10}\right)$. Berger-Parker's index of dominance (d) was used to determine the most abundant species (Magurran 2004). All values are expressed as a mean \pm standard deviation. Helminth communities have been classified at the infracommunity (all helminth infrapopulations within a single oven frog) and component community (all helminth infracommunities within a population of the oven frog) levels. Mann-Whitney's U-test was used to test for differences in helminth richness among the sex. Chi-square test $\left(\chi^{2}\right)$, with Yates correction for continuity, was used for comparing the sex ratio of the frogs. Fisher's exact test (P) was used for comparing the infection between the sexes. Pearson's coefficient correlation ( $r$ ) was used to indicate the relationship between host body size and infracommunity descriptors. Spearman's rank test $\left(r_{s}\right)$ was used to calculate possible correlations between host body size and parasitic abundance. Species covariation was analyzed with the Spearman's test correlation. The species associations was analyzed with a chi-square test, with Yates correction for continuity. The software used was Xlstat 7.5 (Addinsoft 2004). For covariation and associations, the only species considered were those that had at least $10 \%$ occurrences in each of the amphibian's populations (six species).

\section{Results}

\section{Community structure analysis}

The helminth component community of this frog's population consisted of 17 helminth species (Table I). The predominant groups of parasites were trematodes $(53 \%)$ followed by nematodes (35\%); the other groups of parasites were represented by only 1 species (unknown larval cestode species and Centrorhynchus $\mathrm{sp}$.). Helminth diversity $\left(\mathrm{H}^{\prime}=0.90\right)$ and evenness $\left(\mathrm{J}^{\prime}\right.$ $=0.73)$ were high. The metacercariae Bursotrema aff. tetracotyloides was the dominant species $(\mathrm{d}=0.30)$. All helminth parasites of L. latinasus showed the typical aggregated pattern 
of distribution observed in many helminths (Table I). Parasites were found in kidneys, small intestine, large intestine and pharyngeal zone with high level of prevalence and intensity. Of all helminths examined, 3 are assumed to have indirect life cycles ( $G$. repandum, $C$. inopinatus and $H$. longiplexus, and 6 are assumed to have direct life cycles (C. podicipinus, C. parva, C. rara, C. cruzi, A. hylambatis and S. schranki).

At the level of infracommunity, the mean helminth richness was $2.40 \pm 1.50($ maximum $=8)$ species per frog infected. Multiple infections were common, with $0,1,2,3,4,5$, and 8 species occurring in $1,9,12,7,4,2$, and 1 frog, respectively. The mean helminth value of diversity $\left(\mathrm{H}^{\prime}=0.25 \pm 0.19\right)$ and evenness $\left(\mathrm{J}^{\prime}=0.57 \pm 0.36\right)$ were low. The Berger-Parker's index of dominance for the infracommunities was $0.75 \pm 0.20$.

\section{Infection in relation to host's sex and body size}

Of 36 frogs examined, the infection prevalence was $44 \%$ for females, and $53 \%$ for males; there was no significant difference in the number of infected females (16) vs. the males (19) $(\mathrm{P}=0.47)$. The sex ratio of the frogs was not significantly different $\left(\chi^{2}=0.14 ; \mathrm{df}=1 ; \mathrm{P}>0.05\right.$; females $=17$, males $\left.=19\right)$. Parasite richness was not correlated with host sex (MannWhitney's U-test $\left.=182 ; \mathrm{P}>0.05 ; \mathrm{n}_{1}=19 ; \mathrm{n}_{2}=17\right)$. Total length of the frogs ranged from 16 to $31(24.51 \pm 4.16) \mathrm{mm}$,

Table I. Prevalence (\%), total number of parasite (min.--max. intensity), abundance, dispersion index (DI) and site of infection of helminths in Leptodactylus latinasus from Corrientes, Argentina

\begin{tabular}{|c|c|c|c|c|c|}
\hline $\begin{array}{l}\text { Helminths } \\
\text { Site of infection }\end{array}$ & $\%$ & $\begin{array}{l}\text { No. } \\
\text { (min.- } \max .)\end{array}$ & Mean intensity \pm SD & Mean abundance \pm SD & DI \\
\hline Trematoda & & & & & \\
\hline $\begin{array}{l}\text { Glypthelmins repandum } \dagger £ \\
\text { Small intestine }\end{array}$ & 52.8 & $\begin{array}{c}40 \\
(1-5)\end{array}$ & $2.1 \pm 1.3$ & $1.1 \pm 1.4$ & 1.8 \\
\hline $\begin{array}{l}\text { Haematoloechus longiplexus }{ }^{\dagger} £ \\
\text { Lungs }\end{array}$ & 8.3 & $\begin{array}{c}12 \\
(1-10)\end{array}$ & $4.0 \pm 4.2$ & $0.3 \pm 1.7$ & 8.2 \\
\hline $\begin{array}{l}\text { Catadiscus inopinatus }{ }^{\dagger} £ \\
\text { Large intestine }\end{array}$ & 19.4 & $\begin{array}{l}28 \\
(1-7)\end{array}$ & $4.0 \pm 1.9$ & $0.8 \pm 1.8$ & 4.1 \\
\hline $\begin{array}{l}\text { Styphlodora } \mathrm{sp} . \pm £ \\
\text { Kidneys }\end{array}$ & 8.3 & $\begin{array}{c}4 \\
(1-2)\end{array}$ & $1.3 \pm 0.5$ & $0.1 \pm 0.4$ & 1.5 \\
\hline $\begin{array}{l}\text { Bursotrema aff. tetracotyloides } \$ £ \\
\text { Kidneys }\end{array}$ & 19.4 & $\begin{array}{c}158 \\
(6-58)\end{array}$ & $22.6 \pm 18.5$ & $4.5 \pm 12.2$ & 32.3 \\
\hline $\begin{array}{l}\text { Travtrema aff. stenocotyle } £ \\
\text { Mus/Pha-Zon/Mes/Bod-Cav* }\end{array}$ & 22.2 & $\begin{array}{c}129 \\
(2-49)\end{array}$ & $16.1 \pm 13.7$ & $3.7 \pm 9.4$ & 24.0 \\
\hline $\begin{array}{l}\text { Unknown opisthogonimid sp. } \$ £ \\
\text { Pharyngeal zone }\end{array}$ & 8.3 & $\begin{array}{c}26 \\
(6-13)\end{array}$ & $8.7 \pm 3.1$ & $0.7 \pm 2.6$ & 9.1 \\
\hline $\begin{array}{l}\text { Petasiger sp. } * £ \\
\text { Pharyngeal zone }\end{array}$ & 5.6 & $\begin{array}{c}7 \\
(2-5)\end{array}$ & $3.5 \pm 1.5$ & $0.2 \pm 0.9$ & 3.1 \\
\hline $\begin{array}{l}\text { Unknown strigeid species } \$ £ \\
\text { Mesentery }\end{array}$ & 2.8 & 1 & - & $0.03 \pm 0.2$ & 1.0 \\
\hline $\begin{array}{l}\text { Cestoda } \\
\text { Unknown cestode species } \$ £ \\
\text { Liver }\end{array}$ & 2.8 & 1 & - & $0.03 \pm 0.2$ & 1.0 \\
\hline $\begin{array}{l}\text { Nematoda } \\
\text { Cosmocerca podicipinus }{ }^{\dagger} £ \\
\text { Large intestine }\end{array}$ & 38.9 & $\begin{array}{l}46 \\
(1-7)\end{array}$ & $3.3 \pm 2.1$ & $1.3 \pm 2.1$ & 3.3 \\
\hline $\begin{array}{l}\text { Cosmocerca parva }{ }^{\dagger} £ \\
\text { Large intestine }\end{array}$ & 36.1 & $\begin{array}{c}49 \\
(1-13)\end{array}$ & $3.8 \pm 3.1$ & $1.4 \pm 2.6$ & 4.9 \\
\hline $\begin{array}{l}\text { Cosmocerca rara }{ }^{\dagger £} \\
\text { Large intestine }\end{array}$ & 2.8 & 4 & - & $0.1 \pm 0.7$ & 4.0 \\
\hline $\begin{array}{l}\text { Cosmocerca cruzi†£ } \\
\text { Large intestine }\end{array}$ & 2.8 & 4 & - & $0.1 \pm 0.7$ & 4.0 \\
\hline $\begin{array}{l}\text { Schrankiana schranki } i^{\dagger} \\
\text { Large intestine }\end{array}$ & 2.8 & 6 & - & $0.2 \pm 1.0$ & 5.9 \\
\hline $\begin{array}{l}\text { Aplectana hylambatis }{ }^{\dagger} \\
\text { Large intestine }\end{array}$ & 5.6 & $\begin{array}{c}12 \\
(2-10)\end{array}$ & $6.0 \pm 4.0$ & $0.3 \pm 1.7$ & 8.5 \\
\hline $\begin{array}{l}\text { Acanthocephala } \\
\text { Centrorhynchus sp. } \ddagger £ \\
\text { Mesentery }\end{array}$ & 5.6 & $\begin{array}{c}2 \\
(1-1)\end{array}$ & 1 & $0.06 \pm 0.2$ & 1.0 \\
\hline
\end{tabular}

Site of infection: mesentery (Mes), body cavity (Bod-Cav), pharyngeal zone (Pha-Zon), muscle (Mus); †adult, $*$ larvae, ${ }^{£}$ new host, ${ }^{*}$ number of parasites per organs $11 / 54 / 27 / 37$ and percentage of infection per organs 9/18/36/36. 
and weights ranged from 0.47 to $2.64(1.51 \pm 0.66) \mathrm{g}$. Infracommunity descriptors were not significantly correlated with host body size (richness vs. length: $\mathrm{r}=0.04, \mathrm{n}=35, \mathrm{P}>$ 0.05 , and weight: $\mathrm{r}=0.06, \mathrm{n}=35, \mathrm{P}>0.05$; diversity vs. length: $\mathrm{r}=0.01, \mathrm{n}=35, \mathrm{P}>0.05$, and weight: $\mathrm{r}=0.05, \mathrm{n}=35$, $\mathrm{P}>0.05$; evenness vs. length: $\mathrm{r}=-0.06, \mathrm{n}=35, \mathrm{P}>0.05$, and weight: $\mathrm{r}=-0.04, \mathrm{n}=35, \mathrm{P}>0.05)$; there were also no significant correlations between abundance of helminth species and host's body size ( $C$. inopinatus vs. length: $\mathrm{r}_{\mathrm{s}}=0.21, \mathrm{P}>$ 0.05 , and weight: $\mathrm{r}_{\mathrm{s}}=0.23, \mathrm{P}>0.05$; Bursotrema aff. tetracotyloides vs. length: $\mathrm{r}_{\mathrm{s}}=0.24, \mathrm{P}>0.05$, and weight: $\mathrm{r}_{\mathrm{s}}=0.30$, $\mathrm{P}>0.05$; Travtrema aff. stenocotyle vs. length: $\mathrm{r}_{\mathrm{s}}=-0.17$, $\mathrm{P}>0.05$, and weight: $\mathrm{r}_{\mathrm{s}}=-0.23, \mathrm{P}>0.05 ;$ C . podicipinus vs. length: $\mathrm{r}_{\mathrm{s}}=-0.24, \mathrm{P}>0.05$, and weight: $\mathrm{r}_{\mathrm{s}}=-0.28, \mathrm{P}>0.05$; C. parva vs. length: $\mathrm{r}_{\mathrm{s}}=0.20, \mathrm{P}>0.05$, and weight: $\mathrm{r}_{\mathrm{s}}=0.23$, $\mathrm{P}>0.05)$. Nevertheless, only for G. repandum was observed a significant correlation between abundance of infection and host's body size (length: $\mathrm{r}_{\mathrm{s}}=-0.37, \mathrm{P}<0.05$; weight: $\mathrm{r}_{\mathrm{s}}=$ $-0.36, \mathrm{P}<0.05)$ high diversity, with more equitable distribution and increased species richness. Additionally, we observed an increased adult and larval stage infection by trematodes, with the dominant species in the larvae by Bursotrema aff. tetracotyloides. Providing the metacercariae of the Bursotrema aff. tetracotyloides and Travtrema aff. stenocotyle can mature in their respective definitive hosts and considering their high prevalence in L. latinasus, this would suggest L. latinasus could be important prey items for the definitive host and could serve as a main second intermediate host in their life cycle. The definitive hosts for the Bursotrema aff. tetracotyloides's and Travtrema aff. stenocotyle's larval stages are mammals and snakes, respectively (M.I. Hamann, per. obs.).

Adult trematodes were represented by two different ecological groups: One group corresponded to $C$. inopinatus and G. repandum, with indirect life cycles completely in the aquatic environment possibly resembling Diplodiscus subclavatus (Pallas, 1760) and Glypthelmins quieta (Stafford, 1900), respectively (Leigh 1946, Grabda-Kazubska 1976, Smyth and

Table II. Covariation based on Spearman's coefficient correlations $\left(\mathrm{r}_{\mathrm{s}}\right)$ among six common species in Leptodactylus latinasus from Corrientes, Argentina

\begin{tabular}{|c|c|c|c|c|c|c|}
\hline & $\begin{array}{l}\text { Bursotrema aff. } \\
\text { tetracotyloides }\end{array}$ & $\begin{array}{c}\text { Travtrema aff. } \\
\text { stenocotyle }\end{array}$ & $\begin{array}{l}\text { Glypthelmins } \\
\text { repandum }\end{array}$ & $\begin{array}{l}\text { Catadiscus } \\
\text { inopinatus }\end{array}$ & $\begin{array}{l}\text { Cosmocerca } \\
\text { podicipinus }\end{array}$ & $\begin{array}{c}\text { Cosmocerca } \\
\text { parva }\end{array}$ \\
\hline Bursotrema aff. tetracotyloides & 1,000 & & & & & \\
\hline Glypthelmins repandum & $-0,166$ & $-0,011$ & 1,000 & & & \\
\hline Catadiscus inopinatus & $0,344^{*}$ & $0,383^{*}$ & $-0,401^{*}$ & 1,000 & & \\
\hline Cosmocerca podicipinus & 0,109 & 0,050 & $-0,126$ & 0,195 & 1,000 & \\
\hline
\end{tabular}

${ }^{*} \mathrm{P}<0.05$.

\section{Species affinity in the infracommunity}

Two correlations between species were positive and significant: C. inopinatus/Bursotrema aff. tetracotyloides and C. inopinatus/Travtrema aff. stenocotyle and two were negative and significant: C. podicipinus/G. repandum and C. parva/C. podicipinus (Table II). Only two associations were found among the six species considered: C. inopinatus/Bursotrema aff. tetracotyloides $\left(\chi^{2}=5.3, \mathrm{df}=1, \mathrm{P}<0.05\right)$ and $C$. inopinatus/Travtrema aff. stenocotyle $\left(\chi^{2}=10.5, \mathrm{df}=1, \mathrm{P}<0.05\right)$.

\section{Discussion}

Previous reports found the American Leptodactylus's helminth communities composition were predominantly nematodes and exhibited relatively reduced species richness (maximum $=12$; mean $=5.1 \pm 3.2)($ Bursey et al. 2001; Goldberg and Bursey 2002; Goldberg et al. 2002a, b). In this study, L. latinasus's helminth component community harboured
Smyth 1980). The other group was only represented by $H$. longiplexus, characterized by indirect life cycle (Krull 1932, Snyder and Janovy 1996). Haematoloechus longiplexus's second intermediary host is aquatic insect's larvae (e.g. dragonflies) thereby linking the aquatic and aerial environments.

Our data showed adult trematodes are represented by autogenetic species with a definitive host, i.e. L. latinasus, which can live temporarily in an aquatic habitat, and allogenetic species (e.g. larvae) with a definitive host including snakes, birds, and mammals, which can leave the immediate aquatic habitat (Esch et al. 1988, 1997). Alternatively, G. repandum's high colonization is determined by adaptations of its complex life cycle to ensure transmission, without requiring an intermediate host.

Adult nematodes are the second most abundant helminth, consisting of C. podicipinus and C. parva, which presumably have exclusive terrestrial life cycles (Anderson 2000). Our results are similar to those reported for Leptodactylus chaquensis Cei, 1950 captured in the same area (Hamann et al. 2006) 
and both hosts, L. chaquensis and L. latinasus, use the same microhabitat. Adult L. latinasus can live either in the dry and humid earth, near the pond shore, and also in the flooded grass which favours trematode infection. L. latinasus enter the water for a short period to breed or as tadpoles, acting as intermediate and definitive hosts. Furthermore, this amphibian favours a terrestrial microhabitat, where its contact with the soil makes infection possible by nematode larva. The nematode larva can infect through different modes including oral infection (e.g., Aplectana spp.) and skin penetration (e.g., Cosmocerca spp.). In addition, L. latinasus can be the paratenic host of Centrorhynchus spp. (cystacanths), using birds as their definitive hosts (e.g., Falconiformes). The possible intermediary hosts (e.g., coleopterans) of this species are part of L. latinasus's diet (Duré and Kehr 2004).

In general, we did not find a correlation between L. latinasus body size and infection. However, the exception was the adult $G$. repandum; our data suggested smaller hosts had more parasites than larger ones. This result could be explained by ontogenetic changes in the host diet and by behaviour; both characteristics have important roles in parasite recruitment and may be correlated with the host's body size. Similarly, Joy and Dowell (1994) found a negative correlation between the intensity of Glypthelmins pennsylvaniensis Cheng, 1961 and Pseudacris c. crucifer (Wied-Neuwied, 1838) weight in Wayne County, West Virginia. In agreement with Poulin (2001), we found no significant differences between host sex and richness, suggesting host sex is not important factor in structuring parasite communities.

Only one helminth species ( $G$. repandum) had a high prevalence $(>50 \%)$ of infection, this may be explained by the helminth fauna being composed of generalist helminth species. For example, the major helminth species examined in this study are now known to infect other Leptodactylidae species (e.g., L. chaquensis) and a different frog family, sympatric with L. latinasus at Corrientes (M.I. Hamann, per. obs.). L. latinasus shows a wide variation in its helminth fauna, acquiring helminth characteristic of aquatic and terrestrial frogs.

Several amphibian studies of helminth community structures showed they are depauperate and isolationist (Aho 1990; Muzzall 1991; Yoder and Coggins 1996; Bolek and Coggins 2001, 2003). Working with Lysapsus limellus Cope, 1862 and L. chaquensis in Argentina, Kehr et al. (2000) and Hamann et al. (2006) found no fixed pattern, i.e. an intermediate point between isolationist and interactive. In this study, helminth infracommunities of L. latinasus show low diversity and species richness. An individual frog generally harbours only two helminths, with scarce evidence of species affinity. We noted two positive associations for those larval and adult species whose individuals were located in different frog organs. For example, Bursotrema aff. tetracotyloides is located in the kidneys and $C$. inopinatus is found in the large intestine. Likewise, we found a negative correlation between two species at the infection site, with different nutrition (e.g., C. podicipinus /G. repandum), and in different parts of the same organ (e.g., C. parva/C. podicipinus). In agreement with Poulin (2005), interpretation of these interspecific relationships must be considered cautiously, when compared with natural conditions. There was no discernible pattern or structure to L. latinasus's infracommunities; nevertheless these results provide evidence of an interactive and isolationist communities existing in extreme conditions of a continuum.

Acknowledgements. We are grateful to Dr. S.R. Goldberg, for improvements on an earlier draft of this manuscript. This project was partially supported by Consejo Nacional de Investigaciones Científicas y Técnicas (CONICET) from Argentina, through grants PIP 2945 and 2766 to M.I. Hamann and A.I. Kehr, respectively.

\section{References}

Addinsoft 2004. Xlstat for excel, version 7.5. Addinsoft, New York. Aho J.M.1990. Helminth communities of amphibians and reptiles: comparative approaches to understanding patterns and processes. In: Parasite communities: patterns and processes (Eds. G.W. Esch, A.O. Bush and J.M. Aho). Chapman and Hall, New York.

Anderson R.C. 2000. Nematode parasites of vertebrates: their development and transmission. CABI Publishing, Wallingford, UK.

Anderson R.C., Chabaud A.G., Willmott S. 1974. CIH keys the nematode parasites of vertebrates. No. 1. General introduction. Commonwealth Agricultural Bureaux, Farnham Royal, Slough, Headley Brothers Ltd.

Bolek M.G., Coggins J.R. 2001. Seasonal occurrence and community structure of helminth parasites in green frogs, Rana clamitans melanota, from southeastern Wisconsin, U.S.A. Comparative Parasitology, 68, 164-172.

Bolek M.G., Coggins J.R. 2003. Helminth community structure of sympatric eastern American toad, Bufo americanus americanus, northern leopard frog, Rana pipiens, and blue-spotted salamander, Ambystoma laterale, from southeastern Wisconsin. Journal of Parasitology, 89, 673-680.

Brooks D.R., León-Règagnon V., McLennan D.A., Zelmer D. 2006. Ecological fitting as a determinant of the community structure of platyhelminth parasites of anurans. Ecology, 87, S76-S85.

Bursey C.R., Goldberg S.R., Parmelee J.R. 2001. Gastrointestinal helminths of 51 species of anurans from Reserva Cuzco Amazónico, Peru. Comparative Parasitology, 68, 21-35.

Bush A.O., Lafferty K.D., Lotz J.M., Shostak A.W. 1997. Parasitology meets ecology on its own terms: Margolis et al. revisited. Journal of Parasitology, 83, 575-583.

Crump M.L., Scott N.J., Jr. 1994. Visual encounters surveys. In: Measuring and monitoring biological diversity - standard methods for amphibians. Smithsonian Institution Press, Washington.

Duré M.I., Kehr A.I. 2004. Influence of microhabitat on the trophic ecology of two leptodactylids from northeastern Argentina. Herpetologica, 60, 295-603.

Esch G.W., Kennedy C.R., Bush A.O., Aho J.M. 1988. Patterns in helminth communities in freshwater fish in Great Britain: alternative strategies for colonization. Parasitology, 96, 519532.

Esch G.W., Wetzel E.J. , Zelmer D.A., Schotthoefer A.M. 1997. Longterm changes in parasite population and community structure: a case history. American Midland Naturalist, 137, 369-387.

Frost D.R. 2004. Amphibian species of the world: an online reference. Version 3.0 (22 August, 2004). Electronic database accessible at http://research.amnh.org/herpetology/amphibia/ index.htm. American Museum of Natural History, New York. 
Gibson D.I., Jones A., Bray R.A. 2002. Keys to the Trematoda. CABI Publishing and The Natural History Museum, London.

Goldberg S.R., Bursey C.R. 2002. Helminth parasites of seven anuran species from northwestern Mexico. Western North American Naturalist, 62, 160-169.

Goldberg S.R., Bursey C.R., Salgado-Maldonado G., Báez R., Cañeda C. 2002a. Helminth parasites of six species of anurans from Los Tuxtlas and Catemaco Lake, Veracruz, Mexico. Southwestern Naturalist, 47, 293-329.

Goldberg S.R., Bursey C.R., Trujillo J.D., Kaiser H. 2002b. Intestinal helminths of seven frog species from Trinidad Tobago. Caribbean Journal of Science, 38, 147-150.

Grabda-Kazubska B. 1976. Abbreviation of the life cycles of plagiorchid trematodes. General remarks. Acta Parasitologica Polonica, 24, 125-141.

Hamann M.I. 2004. Seasonal maturation of Catadiscus propinquus (Digenea: Diplodiscidae) in Lysapsus limellus (Anura: Pseudisae) from an Argentinean subtropical permanent pond. Physis, 59, 29-36.

Hamann M.I. 2006. Seasonal maturation of Glypthelmins vitellinophilum (Trematoda: Digenea) in Lysapsus limellus (Anura: Pseudidae) from an argentinian subtropical permanent pond. Brazilian Journal of Biology, 66, 85-93.

Hamann M.I., Kehr A.I. 1998. Variación espacio temporal en infrapoblaciones de helmintos y su relación con las fluctuaciones poblacionales de Hyla nana (Anura, Hylidae). Cuadernos de Herpetología, 12, 23-33.

Hamann M.I., Kehr A.I. 1999a. Populational dynamics and ecological relationships between Glypthelmins vitellinophilum Dobbin, 1958 (Trematoda, Macroderoididae) and the host Lysapsus limellus Cope, 1882 (Anura, Pseudidae) in a semipermanent pond of Argentina. Physis, 57, 17-24.

Hamann M.I., Kehr A.I. 1999b. Relaciones ecológicas entre metacercarias de Lophosicyadiplostomum sp. (Trematoda, Diplostomidae) y Lysapsus limellus Cope, 1862 (Anura, Pseudidae) en una población local del nordeste argentino. Facena, $15,39-46$.

Hamann M.I., Kehr A.I., González C.E. 2006. Species affinity and infracommunity ordination of helminths of Leptodactylus chaquensis (Anura: Leptodactylidae) in two contrasting environments from northeastern Argentina. Journal of Parasitology, in press.

Janovy J., Clopton R.E., Percival T.J. 1992. The roles of ecological and evolutionary influence in providing structure to parasite species assemblages. Journal of Parasitology, 78, 630-640.

Jones A., Bray R.A., Gibson D.I. 2005. Keys to the Trematoda. Vol. 2. CABI Publishing and The Natural History Museum, London.

Joy J.E., Dowell B.T. 1994. Glypthelmins pennsylvaniensis (Trematoda: Digenea) in the spring peeper, Pseudacris c. crucifer (Anura: Hylidae), from southwestern West Virginia. Journal of the Helminthological Society of Washington, 61, 227-229.

Joy J.E., Pennington J.L. 1998. Ecology of Megalodiscus temperatus (Digenea: Paramphistomatidae) in red-spotted newts, Notophthalmus $v$. viridescens, from West Virginia. Journal of the Helminthological Society of Washington, 65, 205-211.

Kehr A.I., Manly B.F.J., Hamann M.I. 2000. Coexistence of helminth species in Lysapsus limellus (Anura: Pseudidae) from an Argentinean subtropical area: influence of biotic and abiotic factors. Oecologia, $125,549-558$.

Kehr A.I., Hamann M.I. 2003. Ecological aspects of parasitism in the tadpole of Pseudis paradoxa from Argentina. Herpetological Review, 34, 336-341.
Krull W.H. 1932. Studies on the life history of Pneumobites longiplexus. Zoologischer Anzeiger, 99, 231-239.

Leigh W.H. 1946. Experimental study on the life cycle of Glypthelmins quieta (Stafford, 1900), a trematode of frogs. American Midland Naturalist, 35, 460-483.

Magurran A.E. 2004. Measuring biological diversity. Blackwell Publishing Company, Oxford.

McAlpine D.F. 1997. Helminth communities in bullfrogs (Rana catesbeiana), green frogs (Rana clamitans), and leopard frogs (Rana pipiens) from New Brunswick, Canada. Canadian Journal of Zoology, 75, 1883-1890.

McAlpine D.F., Burt M.D.B. 1998. Helminths of bullfrogs, Rana catesbeiana, green frogs, $R$. clamitans, and leopard frogs, $R$. pipiens in New Brunswick. Canadian Field-Naturalist, $112,50-68$.

Muzzall P.M. 1991. Helminth infracommunities of the frogs Rana catesbeiana and Rana clamitans from Turkey Marsh, Michigan. Journal of Parasitology, 77, 366-371.

Muzzall P.M., Gillillant M.G., Summer C.S., Mehne C.J. 2001. Helminth communities of green frogs Rana clamitans Latreille, from southwestern Michigan. Journal of Parasitology, 87, 962-968.

Pielou E.C. 1966. The measurement of diversity in different types of biological collections. Journal of Theoretical Biology, 13, 131-144.

Poulin R. 2001. Interactions between species and the structure of helminth communities. Parasitology, 122, S3-S11.

Poulin R. 2005. Detection of interspecific competition in parasite communities. Journal of Parasitology, 91, 1232-1235.

Shannon C.E., Weaver W. 1949. The mathematical theory of communication. University of Illinois Press, Illinois.

Smyth J.D., Smyth M.M. 1980. Frogs as host-parasite systems. I. An introduction to parasitology through the parasites of Rana temporaria, $R$. esculenta and $R$. pipiens. Macmillan Press Ltd., London.

Snyder S.D., Janovy J.J., Jr. 1996. Behavioral basis of second intermediate host specificity among four species of Haematoloechus (Digenea: Haematoloechidae). Journal of Parasitology, 82, 94-99.

Tucker R.B., Joy J.E. 1996. Relationships between Glypthelmins pennsylvaniensis (Trematoda: Digenea). Infections and host size. Journal of the Helminthological Society of Washington, $63,42-46$.

Yamaguti S. 1961. Systema heminthum. Vol. 3. The nematodes of vertebrates. Interscience Publishers Inc., New York.

Yamaguti S. 1963. Systema heminthum. Vol. 5. The acantocephala of vertebrates. Interscience Publishers Inc., New York.

Yamaguti S. 1971. Synopsis of the digenetic trematodes of vertebrates. Vol. 1. Keigaku Publishing Company, Tokyo.

Yamaguti S. 1975. A synoptical review of life histories of digenetic trematodes of vertebrates. Keigaku Publishing Company, Tokyo.

Yoder H.R., Coggins J.R. 1996. Helminth communities in the northern spring peeper, Pseudacris c. crucifer Wied, and the wood frog, Rana sylvatica Le Conte, from southeastern Wisconsin. Journal of the Helminthological Society of Washington, 63, 211-214.

Zar J.H. 1996. Biostatistical analysis. Prentice-Hall Inc., Upper Saddle River, New Jersey.

Zelmer D.A., Paredes-Calderón L., León-Règagnon V., García-Prieto L. 2004. Nestedness in colonization-dominated systems: helminth infracommunities of Rana vaillanti Brocchi (Anura: Ranidae) in Los Tuxtlas, Veracruz, Mexico. Journal of Parasitology, 90, 705-710. 